\title{
The Impact of Financial Literacy on Women's Economic Empowerment in Developing Countries: A Study Among the Rural Poor Women in Sri Lanka
}

\author{
Kumari D.A.T. ${ }^{1}$, Ferdous Azam S. M. ${ }^{1} \&$ Siti Khalidah ${ }^{1}$ \\ ${ }^{1}$ Management and Science University, Malaysia \\ Correspondence: Kumari D.A.T., Faculty of Business Studies and Finance, Wayamba University of Sri Lanka, Sri \\ Lanka.Tel: 94-71-753-8467.E-mail: datkumari@gmail.com/datkumari@wyb.ac.lk
}

Received: December 5, 2019

Accepted: December 27, 2019

Online Published: January 31, 2020

doi:10.5539/ass.v16n2p31

URL: https://doi.org/10.5539/ass.v16n2p31

\begin{abstract}
The World Bank, in 2016 defined women's empowerment as a principle for sustainable development and for the fulfilment of the Millennium Development Goals (MDG). Economic empowerment has been identified as a main section of women's empowerment in literature. Economic empowerment directly influences the improvement of women's decision-making power and their financial well-being. Previous researchers have explored many antecedents of women's economic empowerment; among them financial literacy is the most significant determinant in literature. Financial literacy defines as a combination of financial knowledge, financial skills and financial attitudes. Further many researchers argue that financial literacy has greater importance for increasing economic empowerment among women. However, the most important argument is whether financial literacy is a significant determinant of women's economic empowerment in Sri Lankan context. Therefore, the present study mainly focuses on exploring the impact of financial literacy among rural poor on their economic empowerment in the context of Sri Lanka. The sample for this study was drawn from under privileged families who are living under the poverty line in 09 provinces in the country. Altogether 426 questionnaires were distributed and 386 completed questionnaires were taken for final analysis. There were 24 items employed to represents 5 main dimensions to measure the women's economic empowerment (i.e.: 1. Decision-making power, 2. Control over the use of income and expenditure, 3. Leadership in the community, 4. Control over time allocation and 5. Financial wellbeing). And financial literacy was tested based on 25 items which was employed to determine the 04 key factors (i.e.: 1. Financial awareness, 2. Financial knowledge, 3. Financial skills, 4. Financial attitude and 5. Financial behavior). The reliability was measured by Cronbach's Alpha coefficients. Data were collected with the assistance of a researcher administrated questionnaire. The sample was selected based on the multilevel mixed sampling method and the unit of analysis was the women headed households in rural areas representing 25 Districts represented each province of the country. Furthermore, a partial least squares structural equation model (PLS-SEM) was employed as the principle data analysis approach, and Smart PLS 3 was employed as the main analytical software. However, descriptive analysis was done by using SPSS 22.

The findings revealed that, the financial literacy has significant impact on women's economic empowerment among the rural poor. However, when it was considered under separate dimensions, financial wellbeing and control over time allocation have significant impact on financial literacy among rural women. Further it was noted that all the hypotheses were accepted after the analysis. Therefore, researcher concluded that financial literacy can be considered as a significant determinant of women economic empowerment in Sri Lankan context as well. Finally, the researcher provides some suggestions for government policy decision makers to develop financial literacy level for enhancing women's economic empowerment in Sri Lanka.
\end{abstract}

Keywords: decision making power, financial literacy, financial wellbeing, women's economic empowerment

\section{Introduction}

The Organization for Economic Cooperation and Development (OECD) in 2018, defines financial literacy as "a combination of financial knowledge, skill, attitude and behaviour necessary to make sound financial decisions and ultimately achieve individual financial wellbeing". Financial literacy (Fin Lit) is one of the important determinants of women's economic empowerment (WEE). With more Fin Lit, empowers individuals' financial 
decision making power, financial wellbeing, and facilitates to development and affords protection against poverty. Fin Lit will be secured from adverse selections and direct the formal financial system. Accordingly, some vulnerable groups such as low income rural women can increase their incomes, acquire capital, manage risks, empower and work their way out of poverty (Kumari, 2017). Therefore, one of the most important potential consequence of Fin Lit is WEE, which refers to the authority of women to make their own decisions regarding the use of their resources, and leads to the prosperity of families and communities. Thus, many people, particularly the underprivileged and women, show a reluctance to access banking and financial services since they lack knowledge and awareness of finance and financial products. Therefore, they are excluded from financial markets. In addition, in comparison to men, women are lesser accomplished financially on a number of facets. Since the financial welfare of people heavily depends on Fin Lit and as it empowers them economically in the end, the implications of the Fin Lit are not to be undervalued. As a result, during the last few years, the economic empowerment of women by means of Fin Lit has become an area of serious discussion throughout the world (Batra, 2013; Beckmann, 2013; Bhushan, \& Medury, 2013; Arrondel, \& Savignac, 2013; Maheswari, \& Revathy, 2016; Roy \& Jain, 2018; Kumari \& Aluthge, 2018a; Angela, John, \& Ting, 2019). Sri Lanka, a country which aims to be amazing and craves the title "The miracle of South Asia", currently holds a position of lower middle income level in the income category (Global Financial Development Report/GFDR, 2018). Nevertheless, Sri Lanka is a country with an abundance of labour. As stated by the analysis of Sri Lankan sex ratio, the country has a female oriented population with a ratio of 0.96 (male/female) between the male and female population (GFDR, 2018). However, it is regrettable that, in Sri Lanka, a major portion of the unemployed population consists of women. According to the survey report of Department of Census and Statistics (DCS), in the first quarter of 2019, the ratio was 3.4 to 6.9 between the male and female populations (DCS, 2019).

In the local context, the labour force partaking based on gender is $78.9 \%$ male in contrast to $38.5 \%$ female (Global Gender Gap Report/ GGGR, 2018). As citizens of a developing country, Sri Lankan women in rural areas have to confront many challenges so as to obtain financial knowledge. A 52\% of the entire Sri Lankan population is composed of women, and when it comes to the life expectancy rate, women (79\%) and they are 7 years ahead of men (72\%) (GFDR, 2018). Thus, their expenses spread over a longer period of time. In face of these realistic situations, many women are compelled to confront monetary problems. Furthermore, according to the Standard and Poor's Rating Services Global Financial Literacy Survey 2018, around 90\% of women are the sole breadwinners of their families after the death of the spouse or a divorce (S\&P Global Fin Lit Survey, 2018). Fortunately, only an $8 \%$ of women among them are illiterate in a general sense. Among them, rural poor women are lacking in Fin Lit and particularly, lack in financial knowledge and proper financial attitudes and therefore, poor in financial decision making.

In comparison to a number of other Asian countries, Sri Lanka has a financial inclusion rate as high as $73.4 \%$, as stated by the Little Data Book on Financial Inclusion, 2018. All adults (above 15 years) who possess an account in formal financial sector were considered as "Financially Inclusive". Further the report mentioned that Sri Lanka is at the top with the highest rate in women's financial inclusion at a rate of $73.4 \%$. On the other hand, a $26.6 \%$ of the Sri Lankan population is deprived of any form of financial services (S\&P Global Fin Lit Survey, 2018). This exclusion of the formal financial market is the outcome of financial illiteracy and lack of a sound financial attitude. As demonstrated by the S\&P Global Fin Lit Survey in 2018, in almost every country there exists a material gap between the male and female population. When it comes to attributes such as gender, level of education, income and age, Fin Lit rates fluctuate in significant ways. Globally, a 35\% of men are financially literate as opposed to a 30\% of women. As revealed in Sri Lankan adult population, only a 35\% are financially literate and this turns out to be a severe drawback in women's Fin Lit and their wellbeing. Due to the large gap of print literacy (91\%) and Fin Lit (35\%) of female, majority of female are being financially weak (DCS,2018). Other than that, the labour force survey data in 2018 stated that, within Sri Lankan economy, a $74.4 \%$ of female population is economically inactive (DCS, 2018). Hence, the majority of women are being dis-earners and poor. Furthermore, according to the Census of Population and Housing Sri Lanka in 2016, 83\% of adult population in Sri Lanka represents the rural sector. Pertaining condition of women's poor living status results the weak economic empowerment of them. Therefore, this paper is mainly focused on investigating the role of Fin Lit for enhancing the economic empowerment of rural women.

\section{Literature Review}

Empowerment has been discussed by most of researchers (e.g. Golla, Malhotra, Nanda, \& Mehra, 2011; Siddik, 2017) in terms of economic perspective. Economically empowering women is vital both to apprehend women's rights and to achieve broader development goals such as economic growth, poverty reduction, and social welfare. According to Golla et al., (2011), women are said to be economically empowered when women have the ability 
to succeed and advance economically as well as have the power to make correct economic decisions. Many researchers and scholars (e.g. Batra, 2013) argue that WEE promotes inclusive growth in many developing countries. Some researchers (Bongomin, Ntayi, John, Munene, \& Akol, 2017) shows that a large portion of the hard-core poor are the women, because they face social barriers in accessing formal finance such as savings and credits that make it is much harder for them to overcome poverty. Also, because they are more susceptible to becoming poor when they lose the male earning member of the family due to abandonment, divorce or death. Furthermore, Siddik (2017), pointed out that continued disparities between women and men in employment and income opportunities, education, Fin Lit and control over assets demonstrate that development activities are centered on the men.

On the other hand, WEE is vital in defining women's rights (Singh \& Kumar, 2017). Economy and organizations start to realize that women empowerment is a win-win situation not only for women but also for the economy as a whole (Kumari, 2017). Further Deka (2015) argued that economically empowered women are more able to enjoy wellbeing and also help in increasing productivity, economic growth, reducing poverty and enhancing efficiency. Sustainability develops and determines, based on equilibrium structure of society, a society that does not make discrimination or is biased against any social group or gender (Bahmar, 2012). Therefore, empowerment of women promotes sustainable development of a community (Vithanagama, 2016). Further, sustainable social structure comprises social and economic empowerment, Fin Lit and financial freedom of women to access the formal financial system (Siddik, 2017). These factors promote their active involvement in the development of their own, society and whole nation (Savitha \& Polepeddi, 2011). Women being the majority population of society get chances in all spheres of life and definitely become a part of sustainable development (Saha, 2016). According to Kabeer, (2005), as women hold responsibilities of many facets of family structure, which falls under the category of human resources development, empowering women means empowering the whole family. Therefore, Mayoux (2000) noted that women by sitting idle at home but watch the progress of the activity of the family members and interfere in the matter to promote their careers.

According to above discussion, women economic right is definitely an important indicator for enhancement of their status. Therefore, women's financial knowledge should be encouraged in terms of Fin Lit by educating more employment avenues and financial awareness etc., thereby creating economic freedom in women (Hung, Yoong, \& Brown, 2012). This dimension covers strength of financial decision making that benefits the economic growth, financial access, credit, social cohesion, local participation and interaction of formal financial transactions, etc., for betterment of their lives (Mayoux \& Hartl, 2009). In this regard, developing countries give priority to Fin Lit for more for financial inclusion in order to improve the economic empowerment of their women. However, in the new global economy, women's empowerment has become an important hurdle for countries to be able to achieve development goals such as economic growth, poverty reduction, health, education and welfare (Golla et al., 2011; Maheswari \& Revathy, 2016; Kumari \& Subrahmanyam, 2017; Roy \& Jain, 2018; Lyons, Angela, John, \& Ting, 2019). Therefore, researchers are interested to investigate the relationship between WEE and Fin Lit.

\subsection{Measures of Women's Economic Empowerment}

According to the previous literature, there are many measurement indicators for the WEE. Out of them, 26 items were considered for the exploratory factor analysis and factor laddered into 5 main measures. And finally, 24 items which were taken based on their high reliability representing high Cronbach alpha values for present research context. Therefore, as explained in following section, five main dimensions such as economic decision making power, control over the use of income and expenditures, leadership in the community, control over the time allocation and financial wellbeing can be employed in the present study to measure economic empowerment of the rural women.

\section{Decision making power}

As defined by Domingo, Holmes, O'Neil, Jones, Bird, Larson, Presler-Marshall, \& Valters, (2015), "Decision-making power is the ability to influence decisions that affect one's life - both private and public". It is important for women to have formal access to positions of authority and to decision making process in order to have a decision making power in the public domain (Islam \& Reza, 2012; Haque \& Zulfiqar, 2016; Hung, Yoong, $\&$ Brown, 2012). The power of decision making is a combination of access, capabilities and actions that determines whether women have effect over the society or their private life. When studying, economic empowerment, the decision making power is considered under the financial point of view (Deka, 2015; Karunathilake, 2016). Therefore, based on the previous researchers' definitions and explanations, in the present research context, the decision making power is referred as: to the power of poor rural women to make household 
economic decisions for achieving short and long term economic wellbeing in their households.

\section{Control over the use of income and expenditures}

The next important issue is the control over the use of income and expenditure, because not having a proper control over this factor will result in spending money out of track. To control the income and expenditure, it is best to directly prepare the detailed document on controlling an income and expenditure, while developing the budget (Deka, 2015; Rai, 2019). The household budget should be communicated with all the relevant staff. Under the WEE, controlling power of the income and expenditure of family members as well as controlling herself is a significant phenomenon of her empowerment (Deka, 2015; Domingo et al., 2015; Adami, Carosi, \& Sharma, 2018). Therefore, based on the previous researchers' definitions and explanations, in the present research context, controlling the use of income and expenditure termed as; authority and willingness of poor rural women to control the over expenditure of their families with the purpose of using this resources to productive ways.

\section{Leadership in the community}

Over the years, women have been the linchpin of communities as they are actively involved in community initiatives in various ways. Even though it is not noticed oftentimes, the role of these unrewarded heroes of community actions has become indispensable (Deka, 2015). Especially, in some communities like rural poor, women have established themselves as leaders in community development and acquired the skills that have brought positive change to their communities. Women leaders also play key roles in establishing and maintaining important relationships and networks among the members of the community (Gilabert, Gilabert, Dietz, \& Grabs, 2016; Karunathilake, 2016). They face cultural, economic, and social barriers in leading the community and in many cases overcoming those barriers become their motivation. It can be observed that, even though their involvement and contributions have uplifted the evolution and the nature of community development, they have not been given proper acknowledgement for those contributions. The results of previous studies provide deeper insights into women's thinking about leadership and community development (Arora, 2016; Maheswari, 2016; Haque et al., 2018; Bonga et al., 2016; Singh et al., 2017; Lusardi et al., 2017; Roy et al., 2018). Therefore, based on the previous researchers' definitions and explanations, leadership in the community for present study means the extent to which poor rural women can influence the common decisions of community and degree of other community people willing to accept their views.

\section{Control over the time allocation}

A study conducted by Hoque and Itohara (2009) reported that the time allocation is contributing to an extent in planning family activities and participating in family leisure time based on the decision making power of the rural women. The authors also stated that the time spending programme among family members contributes to develop the leadership of the rural women (Singh \& Kumar, 2017; Deka, 2015; Karunathilake, 2016). This study was conceptualized by considering five important dimensions of WEE that identifies the basic five principles in which empowerment is achieved, in which control over the time allocation was identified as an important dimension (Swamy, 2014; Deka, 2015; Lusardi et al., 2017; Roy et al., 2018). Therefore, according to this research context, control over the time allocation means the ability and willingness of poor rural women for allocating their time for different tasks and the ability to decide their leisure time in between their day to-day work schedule.

\section{Financial wellbeing}

Another sub-dimention of the study is financial wellbeing, contributing to some extent in generating economic empowerment and participation in financial decision making power of the rural women (Dash, Prasad, \& Koshy, 2016). Financial wellbeing determines whether women are capable of making decisions about household matters like buying household assets and managing financial resources, having access to bank, having future financial security, having ability to make choices or having enough assets to do day to day financial transactions (Deka, 2015; Maheswari, 2016; Haque et al., 2016; Bonga et al., 2016). Therefore, based on the previous researchers' definitions and explanations in this research context, financial wellbeing referred as: ability of poor rural women to fully meet current and ongoing financial obligations and feel secure in their financial future, and is able to make choices that allow them to enjoy life.

\subsection{Measures for Financial Literacy}

Most of the previous researchers identified that measurement of Fin Lit should be differentiating to match with respective socio economics contexts (Saha, 2016; Singh et al., 2017; Roy \& Jane, 2018; Lusardi et al., 2019). Moreover, previous researchers have measured the degree of Fin Lit in most of the developing countries such as 
India (e.g. Setty, 2012; Bhushan \& Medury, 2013), Bangaladesh (Ferdous \& Polonsky, 2013; Khandker, \& Cartwright, 2006), Zimbabwe (e.g. Bonga \& Mlambo, 2016) Pakistan (e.g. Zulfiqar, 2016). Comparatively researchers have paid less attention for the Sri Lankan context to determine the level of Fin Lit. However, Heenkenda (2014) has done a comprehensive study to determine the degree of Fin Lit in general context. As measurements adopted by previous researchers provide direction to select most appropriate dimensions to the present context, some of the studies have been identified financial knowledge and financial behavior as main dimensions of Fin Lit. Most of the previous researchers, irrespective to the nature of the country, have adopted the financial knowledge to determine the level of Fin Lit in the respective countries. Further financial education and financial well-being are also considered as important dimensions. However, Thapa (2015) stated that financial education is an input for developing Fin Lit. But on the other hand, Morgan, \& Trinh, (2019) argued that financial decision making and financial well-being are actually the consequences of Fin Lit. Further several researchers (e.g. Mouna, \& Anis, 2017) emphasised that Fin Lit of rural communities should be determined in knowledge as well as behavioral perspectives. Moreover, Heenkenda (2014) noted that financial knowledge can be convert into behavior based on financial skills and financial attitudes. Based on an empirical research done on Indian women, Arora (2016) found that three parameters-financial knowledge, financial behavior and financial attitude can be used to assess the level of Fin Lit and also studied that the general awareness about financial planning tools and techniques among women remains poor. Furthermore, this study concluded that women are better in terms of financial attitude and behaviour as compared to financial knowledge.

Therefore, with the support of previous research, this study used 30 factors to measure the Fin Lit in exploratory factor analysis and those factors were categorized into 5 main dimensions; such as financial knowledge, financial awareness, financial skills, financial attitudes and financial behavior as they can be considered as the most suitable dimensions for defining Fin Lit. Further, while considering the reliability there were 5 factors removed out of 30 due to the low level of Cronbach alpha in the present research context.

\subsection{Women's Economic Empowerment as a Consequences of Financial Literacy}

Most of the previous researchers elaborated consequences of Fin Lit in different perspectives. Mainly most prominent recent researchers (E.g. Bonga \& Mlambo, 2016) argued that a financialy literate individual is someone who can deal with the formal financial system in the country and make a considerable contribution to their local economy. Furthermore, Bhushan, \& Medury, (2013) explored that people may move into the formal financial system by empowering the decision making ability of individuals through Fin Lit. However, Aggarwal, (2014) emphasised that economic decision making power is just one dimension of people's economic empowerment. On the other hand, some researchers (e.g. Bahmar, 2012; Kumari, \& Aluthge, 2018b) discussed ultimate result of Fin Lit is making financial well-being of those individuals. According to Aggarwal, (2014), personal financial well-being contributes to the efficiency and prosperity of the national economy. Moreover, Arora, (2016) noted that Fin Lit is a component of human capital that can be used in financial activities to increase expected lifetime utility from consumption (i.e., behaviors that enhance financial well-being). Accordingly, a composite definition of Fin Lit that is built of those given by Presidents Advisory Council on Financial Literacy (PACFL) (2008) and various researchers is that Fin Lit is the knowledge of basic economic and financial concepts, as well as the ability to use that knowledge and other financial skills to manage financial resources effectively for a lifetime of financial well-being (Bahmar, 2012). Therefore, Fin Lit can be considered as the ability to process financial information and make informed decisions about personal finance. Recently, developed countries have shown a growing interest towards the concept of Fin Lit while in the developing world it is now being considered as potentially a vital determinant of household well-being (Adam, Boadu, \& Frimpong, 2018). As a result, individuals' Fin Lit is fundamental in achieving their financial well-being. Although this situation is influenced by several external forces such as economic factors and policy structures adopted by government and private sector, decisions are ultimately made by individuals (Kumari, 2016a). Therefore, financial satisfaction is an individual's subjective perception of his or her contentedness with financial resources (Lusardi, 2019). Financial empowerment has long been acknowledged as a component of well-being (Saha, 2016) and has received attention in finance related studies such as financial strain, risk management issues, lack of financial skills and empowerment issues (Kumari, 2017; Lusardi, \& Scheresberg, 2017). Therefore, the researchers noted that economic empowerment of the society become direct consequences of Fin Lit and it can happen through the financial empowerment process.

However, the present research focuses on rural poor women for analyzing the Fin Lit and its impact on WEE. Most of the researchers argued that rural women don't have sufficient opportunities to develop their financial knowledge (Lusardi \& Olivia, 2008). Further, some are emphasizing that sufficient financial infrastructure is not available in rural areas, (e.g. Aggarwal, 2014), making the situation even more crucial when they become poor 
(Singh et al., 2017). Moreover, researchers have revealed that the level of Fin Lit is significantly different among different genders of developing countries.

Gender is one of the main variables researched, and the majority of the evidence indicates that women generally show lower indices of Fin Lit than men (Kumari \& Aluthge, 2018a; Lusardi \& Mitchell, 2011; Lusardi \& Wallace, 2013; Lusardi, \& Olivia, 2014; Morgan \& Trinh, 2019; Lusadi, 2019). This broadens the evidence that women face greater difficulties than men in making financial calculations, which, in addition to not having the basic knowledge about financial concepts and lower level of skills, make responsible financial decisions more difficult to achieve. This can be considered a worrisome factor because women are entering in the labor market and engaging more in making financial decisions, income management and indebtedness in addition to the usual role of being responsible for the household. Further Lusardi, (2006) found that having little Fin Lit, women faced difficulty in retirement calculation and they are much more likely to rely on family, friends and advisers for their financial planning. Furthermore, Dash, Prasad, \& Koshy, (2016) found that women are not participating fully in investment planning and not as comfortable as men in seeking financial advice. The previous authors further reveals that education plays an important role in the Fin Lit of women. Maheswari, \& Revathy, (2016) suggested that improvement of Fin Lit would support making better financial decisions and proper utilization of financial services and products among women. It would also help in wealth accumulation and financial wellbeing which will lead to their personal development as well as social development. Singh et al., (2017) found that the most popular investment method among the females in Pune, India is systematic investment plan. According to the above discussion, measuring Fin Lit among rural women and its impact on WEE become practically an important research area to be further investigated. Therefore, based on the previous literature, researcher developed a conceptual framework as to examine the causal relationship between these variables as follows.

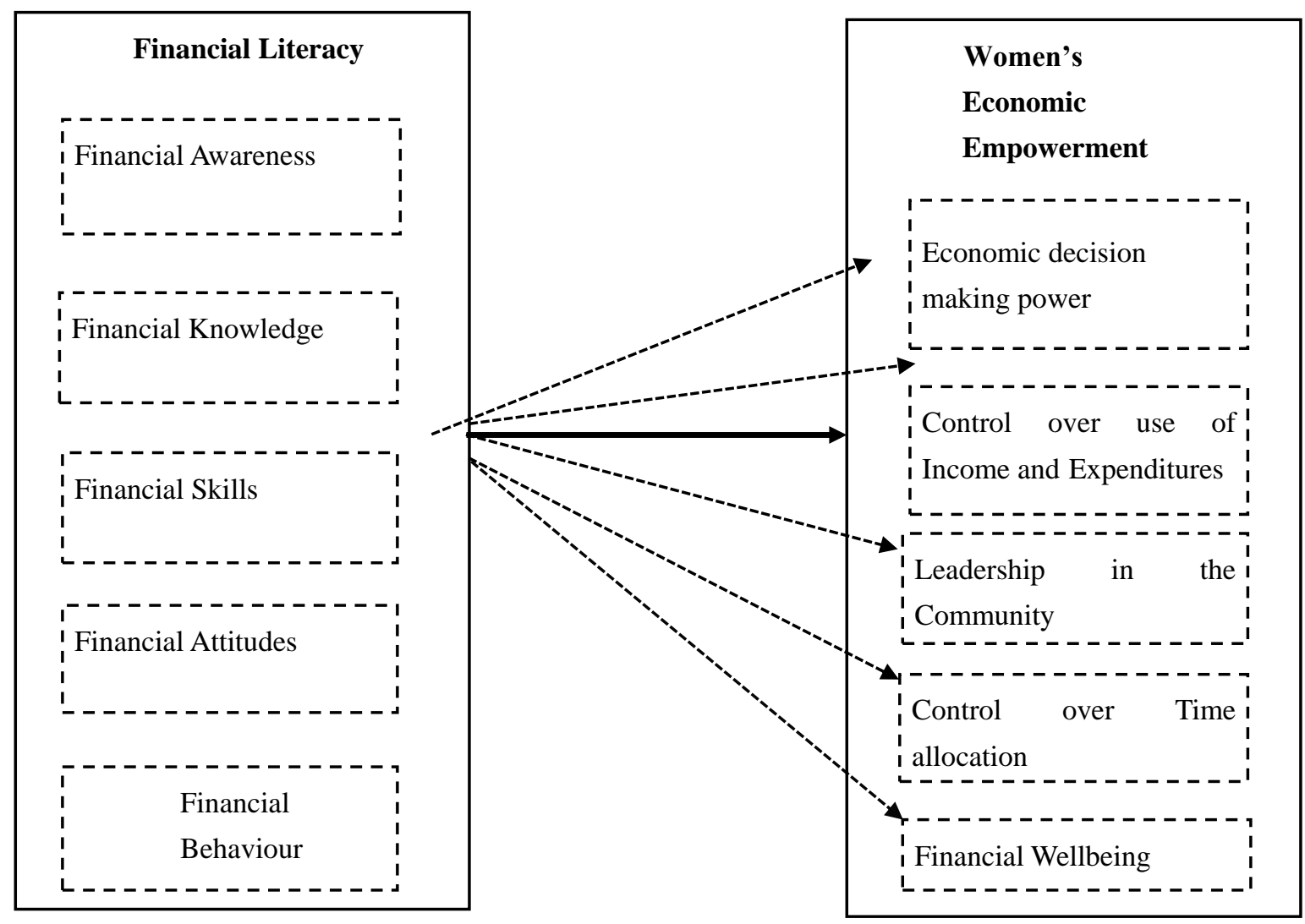

Figure 1. Conceptual Framework

\section{Hypothesis Development}

There are several studies that directly investigated the impact of Fin Lit on WEE in some perspective. Specially, Fin Lit has a positive influence on economic decision making power (e.g. Lusardi \& Tufano, 2015; Lusardi \& Scheresberg, 2013; Deka, 2015 etc.), control over use of income and expenditures (e.g. Arora, 2016; Peter \& Long, 2019; Joshi, 2013etc.), leadership in the community (e.g. Siddik, 2017; Golla et al., 2011; Krishna, 2003 etc.), control overt the time allocation (e.g. Udegbe, 1996; Ravallion \& Chen, 2003; Bhalla, 2007 etc.), and 
financial wellbeing (e.g. Zulfiqar, 2015; Taft, 2013; Bhabha et al., 2014; etc.) of women. Based on the former discussion, the researcher has developed some testable hypotheses to determine the relationship between Fin Lit and WEE. One main hypothesis was developed as H1 to examine the direct relationship. Additionally, 5 sub-hypotheses were developed to test the dimensional relationship of WEE and Fin Lit. Sub-hypotheses helped to identify the most significant dimensions of WEE which has been mostly affected by the level of Fin Lit on rural poor women's context. Therefore, hypotheses were developed as follows.

\section{H1: Financial literacy is positively influenced on the economic empowerment of rural poor women in} Sri Lanka.

As H1 is mainly concentrated on the relationship between Fin Lit and economic empowerment of rural women in Sri Lanka, it is important to check the relative influence on financial literacy for each dimensions of WEE. Accordingly, five sub hypotheses were developed as well.

H1a Financial literacy is positively influenced on the economic decision making power of rural women in Sri Lanka.

H1b Financial literacy is positively influenced on the control over use of income and expenditures of rural women in Sri Lanka.

H1c Financial literacy is positively influenced on the leadership in the community of rural women in Sri Lanka.

H1d Financial literacy is positively influenced on the time allocation for the leisure activities of rural women in Sri Lanka.

H1e Financial literacy is positively influenced on the financial wellbeing of rural women's in Sri Lanka.

\section{Method}

The research problem was identified based on certain issues relating to empowerment of women in rural areas in Sri Lanka. The identified research problem was justified by literature based on the theoretical and literature gaps. Conceptual framework and hypotheses were developed based on the theory and literature. After refining the conceptual framework, the main study was designed by adopting the positivist research paradigm. This study focused on the impact of Fin Lit on the economic empowerment of rural women. The conceptual model has been developed by deductive reasoning of existing theories and literature. Accordingly, deductive quantitative approach was adopted by considering empirical nature of the study.

There are five main variables Fin Lit in the conceptual model, such as financial awareness, financial knowledge, financial skills, financial attitudes, and financial behaviour based on the recommendations of previous researchers. Further, it was recommended to employ 05 variables to measure women empowerment which are more applicable in determining WEE in developing countries like Sri Lanka. Those are economic decision-making power, control over use of income and expenditures, leadership in the community, control over the time allocation, and financial wellbeing. Those factors were identified from several previous studies (e.g. Alkire et al., 2012; Pauline et al., 2016; Siddik, 2017) conducted in similar socio cultural contexts. The exploratory factor analysis was conducted with respective two variables. Accordingly, this study revealed 5 main factors with 25 items out of 30 for Fin Lit and found another 5 factors with 24 items out of 26 items for WEE.

In present research context, since the researcher attempts to analyze latent factors represented by multiple variables in Fin Lit, and economic empowerment of rural women, the Structural Equation Modeling (SEM) was adopted as a most appropriate approach for data analysis (Hair, Hult, Ringle, \& Sarstedt, 2017). And also, the researchers specified the Smart-PLS 3 as the main analytical software due to the nature of the second order construct in the present study. The target population for the study was defined as "Rural poor women in Sri Lanka with fixed consumption expenditure per month below Rs. 4,677". According to Household Income and Expenditure Survey in 2016 conducted by Department of Census and Statistics Sri Lanka, overall poverty head count index in Sri Lanka was reported as 4.1\%. That means 843,913 of people in Sri Lanka are below the poverty line. Sample was selected by adopting to several stages recommended by well-known authors of social researches. Accordingly, it was decided that the appropriate sample size is 386, based on the Cochran's sample size estimating formula. As present study intends to adopt SEM as the main statistical techniques, minimum sample size should be 384 (Litze Hu \& Bentler, 1999; Kenny, 2012; Kline, 2011). Even though, Sekaran \& Bougie, (2016) noted that non response rate is minimum in collecting data from researcher administrated questionnaire, the researcher decided to increase the sample size by considering $10 \%$ contingency factor accounting to some possible missing data. Accordingly, the total sample size was calculated as $(384 / 90 \mathrm{X} 100=$ 426) 426. As data collection was done from all 09 provinces in the country, it was decided to administrate the 
questionnaires by well experienced data enumerators. The multilevel mixed sampling method was adopted to selecting the sample.

\section{Findings and Discussion}

Initially, the model was tested in theoretical and literature perspective and then it was statistically justified by confirmatory tetrad analysis (CTA). According to the findings of CTA, Fin Lit and WEE were recognized as reflective latent variables in the present model. Therefore, measurement model assessments criteria should be tested with respect to the reflective nature of the variables (Memon, Cheah, Ramayah, Ting, Chuah, \& Cham, 2019). As per the Hair, Gudergan, Ringle, \& Sarstedt, (2018) when two variables are in reflective second order constructs, repeated indicator approach should be followed. But, latent variable must have the equal number of indicators of low order constructs (Hair, Sarstedt, Ringle, \& Gudergan, 2018). Due to the different number of indicators in different dimensions, the researchers employed the two-stage approach in PLS-SEM. And followed the basic statistical test for reflective variables in measurement model as well as the structural model.

Fin Lit and WEE were identified as reflective variables as explained by the previous studies (Thorat, 2006; Aduda \& Kalunda, 2012; Demirg-Kunt \& Klapper, 2013; Kelegama et al., 2014; Park, 2015; Bonga \& Mlambo, 2016). In the main hypothesis, it described the direct relationship of the independent and dependent variables. According to the main objective of the study, it is needed to examine the influence made by overall Fin Lit on WEE and influence of Fin Lit on each dimension of the economic empowerment among rural poor women in Sri Lanka. Therefore, the two constructs were measured as reflective, second-order constructs in the structural model. Accordingly, reflective higher order constructs were adopted with latent variable scores and results are given in Figure 2 and detailed results in Table 1.

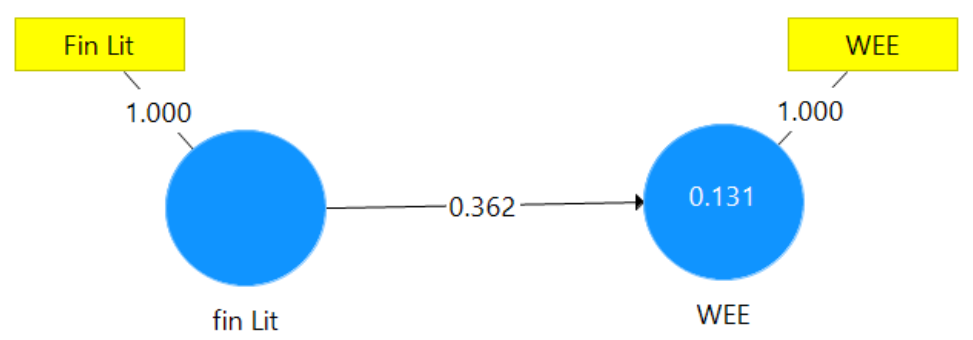

Figure 2. Direct relationship between Fin Lit and WEE

Source: Survey Data 2019

Table 1. Significance of the Direct Relationship between Fin Lit and WEE

\begin{tabular}{|c|c|c|c|c|c|c|c|c|c|}
\hline Path & $\beta$ & $\begin{array}{c}\text { Sample } \\
\text { Mean (M) }\end{array}$ & $\begin{array}{l}\text { Standard } \\
\text { Deviation } \\
\text { (STDEV) }\end{array}$ & T Statistics & P Values & Bias & $5.00 \%$ & $95.00 \%$ & $\begin{array}{c}\text { Hypothesis } \\
\text { H1 }\end{array}$ \\
\hline $\begin{array}{c}\text { fin Lit -> } \\
\text { WEE }\end{array}$ & 0.362 & 0.36 & 0.052 & 6.93 & 0.000 & -0.001 & 0.273 & 0.445 & Accepted \\
\hline
\end{tabular}

\section{Source: Survey Data 2019}

As per the findings revealed in Figure 1, R2 value (coefficient of determination) is reported as 0.131 and respective path coefficients are estimated as statistically significant $(b=0.362, t=6.93, p=0.000)$. The $\mathrm{BCa}$ confidence intervals were at an acceptable range (lower $=0.273$ and upper $=0.445$ ) (table 1$)$. Therefore, the results demonstrated that $13.1 \%$ of WEE is represented by Fin Lit among the rural poor women in Sri Lanka. Further respective $\beta$ value noted that when Fin Lit increased by one unit, WEE will be positively changed by 0.362 units in the present research context. The overall findings imply that Fin Lit has a significant positive impact on the level of economic empowerment of rural poor women in Sri Lanka. Therefore, it is noted that main hypothesis (H1), "financial literacy is positively influenced on the economic empowerment of rural poor women in Sri Lanka" was supported by the empirical evidences of present research context. Accordingly, the results clearly indicated that Fin Lit has a significant positive influence on WEE in rural poor women in Sri Lanka.

Further, the researcher has developed several sub hypotheses with the purpose of determining the most 
significant dimension of WEE influenced by Fin Lit. In order to test aforesaid sub hypotheses, the following structural model was constructed to determine the path coefficients from Fin Lit to each dimension of WEE (see Figure 2). The statistical outcomes of the same model are summarized in Table 2.

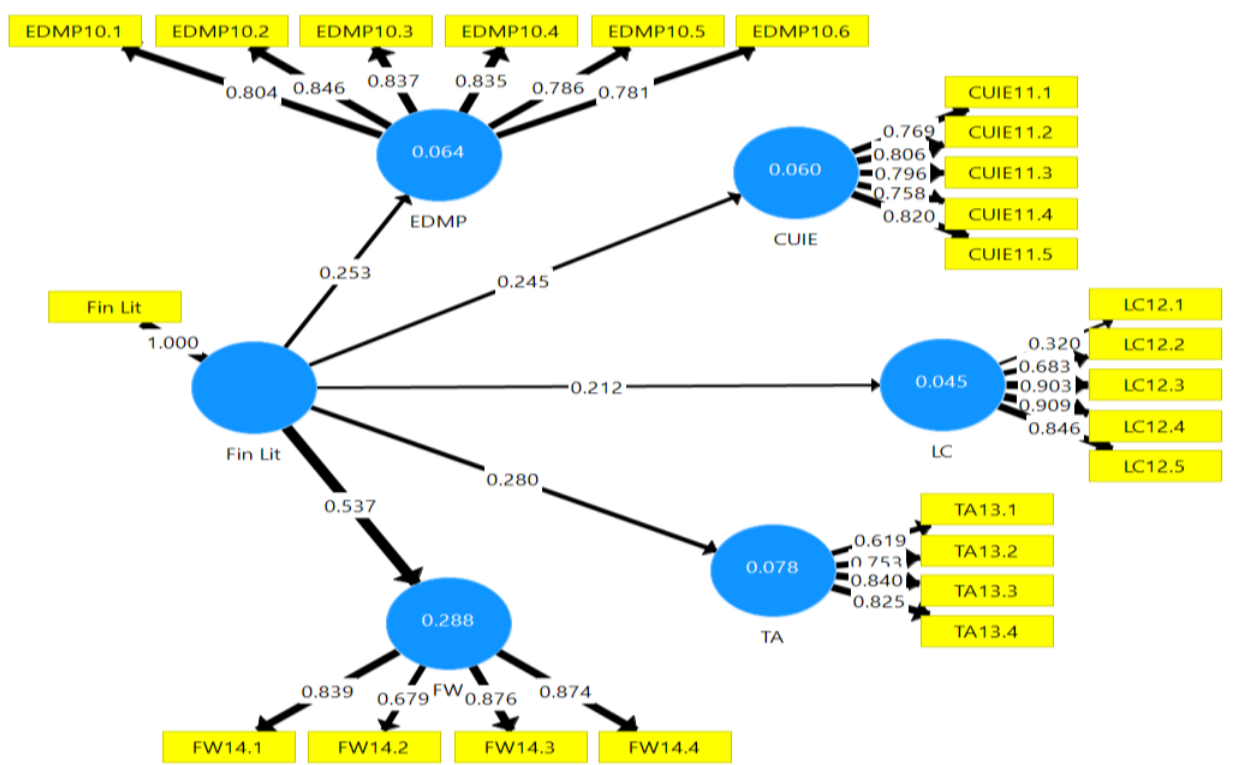

Figure 3. Specific Relationship between Fin Lit and WEE Dimensions

Table 2. Significance of the specific Relationship between Fin Lit and WEE's dimensions

\begin{tabular}{cccccccccc}
\hline Path & $\beta$ & $\begin{array}{c}\text { Sample } \\
\text { Mean (M) }\end{array}$ & $\begin{array}{c}\text { Standard } \\
\text { Deviation }\end{array}$ & T Statistics & P Values & Bias & $2.50 \%$ & $97.50 \%$ & Hypotheses \\
\hline $\begin{array}{c}\text { Fin Lit }-> \\
\text { EDMP }\end{array}$ & 0.253 & 0.260 & 0.055 & 4.646 & 0.000 & 0.006 & 0.139 & 0.353 & H1a: Accepted \\
\hline $\begin{array}{c}\text { Fin Lit -> } \\
\text { CUIE }\end{array}$ & 0.245 & 0.253 & 0.047 & 5.230 & 0.000 & 0.008 & 0.15 & 0.334 & H1b: Accepted \\
\hline $\begin{array}{c}\text { Fin Lit -> } \\
\text { LC }\end{array}$ & 0.212 & 0.223 & 0.049 & 4.371 & 0.000 & 0.01 & 0.118 & 0.296 & H1c: Accepted \\
\hline $\begin{array}{c}\text { Fin Lit -> } \\
\text { TA }\end{array}$ & 0.280 & 0.286 & 0.048 & 5.831 & 0.000 & 0.005 & 0.18 & 0.367 & H1d: \\
\hline $\begin{array}{c}\text { Fin Lit -> } \\
\text { FW }\end{array}$ & 0.537 & 0.538 & 0.038 & 14.007 & 0.000 & 0.002 & 0.456 & 0.604 & H1e: Accepted \\
\hline So
\end{tabular}

Source: Survey Data 2018

The findings revealed that the economic decision-making power of rural poor women is found to be positively influenced by Fin Lit by recording a statistically significant path coefficient $(b=0.253, t=4.646, p=0.000)$ with acceptable range of $\mathrm{BCa}$ confidence intervals (Table 2). Further, findings revealed (table 2) that Fin Lit has a positive significant impact on the control over the use of income and expenditures (CUIE.) within the households of rural poor women due to the respective path coefficients which were statistically significant $(b=0.245, t$ $=5.230, \mathrm{p}=0.000)$. The $\mathrm{BCa}$ confidence intervals are at an acceptable range (lower $=0.15$ and upper $=0.334$ ). The third dimension of WEE is identified as leadership in the community (LC) among rural women. Most of the literature strongly supported the positive impact of Fin Lit on LC and it is tested in the present structural model as well. According to the findings, the path coefficients are found as statistically significant $(b=0.212, t=4.371$, $\mathrm{p}=0.000$ ) and $\mathrm{BCa}$ confidence intervals are at an acceptable range (lower $=0.118$ and upper $=0.296$ ). The fourth dimension of WEE is nominated as time allocation (TA) which is to what extent the rural women has power and authority of control over their time and the time of other members living in a household. According to the findings, the TA of rural poor women is positively influenced by Fin Lit with statistically significant path coefficients $(\mathrm{b}=0.280, \mathrm{t}=5.831, \mathrm{p}=0.000)$ in an acceptable range of $\mathrm{BCa}$ confidence intervals (lower $=0.18$ and 
upper $=0.367)$. Finally, Fin Lit is found to have a significant influence on financial wellbeing $(\mathrm{FW})$ of rural woman by reporting significant path coefficients $(b=0.537, t=14.007, p=0.000)$ with acceptable range of $\mathrm{BCa}$ confidence intervals (lower $=0.456$ and upper $=0.367$ ). According to the overall findings, all $\mathrm{p}$ values are below 0.05 and all the $t$ value are above 1.96 . Therefore, all 5 sub hypotheses are empirically supported.

\section{Conclusion and Implications}

The results of aforesaid analysis revealed that the most significant dimension of WEE influenced by Fin Lit is financial well-being (FW) with highest $t$ value among the other dimensions. The leadership in the community was recognized as the least influential variable of WEE as the respective path coefficient has the lowest $t$ value. Further, it was observed that Fin Lit has a significant positive influence on each dimension of WEE in the present research context. The findings of this study is confirmed by previous literature as well. According to the previous literature, most of the studies found that, there is a positive relationship between Fin Lit and WEE (Singh \& Kumar, 2017; Bhargava, 2017; Arora, 2016; Wellington \& Mlambo, 2016; Bannier \& Schwarz, 2018).

Further findings of the present study were confirmed that economic decision-making power is significantly influenced by Fin Lit among the rural women in Sri Lanka. This finding is fully aligned with the previous literature on Fin Lit and economic decision-making power of rural women (e.g. Lusardi \& Tufano, 2015; Lusardi \& Scheresberg, 2013; Deka 2015 etc.). Furthermore, the outcome of structural model implied that Fin Lit has significant impact on control over use of income and expenditure (CUIE). This relationship is also tested in previous literature (e.g. Arora, 2016; Mathivathani \& Velumani, 2014; Joshi, 2013 etc.) which identified the same positive relationship between those two variables. Fin Lit has a significant contribution for developing community leadership among the rural women in Sri Lankan context. Accordingly, the results of the present research further confirmed by the empirical results revealed in most of the previous studies (e.g. Siddik, 2017; Golla et al., 2011; etc.). Moreover, outcome of the structural model implied that there is a significant impact of Fin Lit on the time allocation (TA) of rural women in Sri Lanka. The relationship between Fin Lit and (TA) as a dimension of WEE is also explained in some previous literature (eg: Zulfiqar, 2015; Devi, 2016; Kasman, Heuberger, \& Hammond, 2018 etc.,) as a positive relationship and those findings are aligned with the results of the present research. Finally, it was further noted that Fin Lit has significant impact of the financial wellbeing $(\mathrm{FW})$ of rural women. The previous literature also emphasizes that Fin lit is playing a main role for enhancing the financial wellbeing of rural poor communities (Hashemi, Schuler, \& Riley, 1996; Madhubhashini, 2015; Sanjib, 2016; Klapper, Lusardi, \& Van Oudheusden, 2015; Singh \& Kumar, 2017) and the findings confirmed in the present research context as well.

According to the previous literature, WEE is considered in different aspects but no one considered all the dimensions together to determine the WEE. Moreover, there isn't any research study which was conducted on local context where rural poor women are focused. Therefore, it can be concluded that present research is able to fill the literature gap emphasized by the researcher based on the relationship between Fin Lit and WEE. Even though the present study revealed that there is a significant relationship between Fin Lit and WEE, as per the economic indicators poor women are severely facing the financial illiteracy problem in Sri Lankan context. However, print literacy level and education level of the country is at high level. Therefore, academics should investigate the reasons behind this gap between print literacy and Fin Lit among population groups living in the country.

Policy makers of the country mainly represent government and non-government agencies. It is the responsibility of a government to develop economy and achieve developmental goals. When improving the living condition of population, more attention should be paid to the rural poor category. In Sri Lanka, 74\% of people are living in rural areas. Further, 1.4 million of households are headed by females (Source). Therefore, improving the living condition of rural poor women can be considered as a key aspect of the development process of Sri Lanka. Therefore, enhancing WEE of rural sector should be enhanced by improving Fin Lit and financial inclusion. Therefore, the separate division of finance ministry should be assigned to enhance the economic empowerment of rural women and to conduct the awareness programmes about the formal financial sector together with both public and private sector formal financial institutions. Further the researchers recommend to include some information about the formal financial instruments into the school syllabus of primary education with the purpose of minimizing the gap between Fin Lit and print literacy. Further, some practical components should be included in to those syllabuses to give hands-on experience to children about the application of new technology. Finally, government can incorporate the welfare programmes with economic empowerment among women. Otherwise, special welfare scheme like Sumurdi can be implemented for rural poor women to enhance their economic empowerment. Accordingly, rural poor females may become economically sound to take part an active role in economic decision-making in their households and leadership in their communities. 


\section{References}

Adam, A. M., Boadu, M. O., \& Frimpong, S. (2018). Does Gender Disparity in Financial Literacy Still Persist After Retirement? Evidence from Ghana. International Journal of Social Economics, 45(1), 18-28. https://doi.org/10.1108/IJSE-06-2016-0159

Adami, R., Carosi, A., \& Sharma, A. (2018). Retirement Saving in the UK: A Life-Cycle Analysis. Studies in Economics and Finance, 35(1), 109-136. https://doi.org/10.1108/SEF-01-2017-0018

Aggarwal, N. (2014). Financial Literacy among farmers: Empirical evidence from Punjab. Pacific business review international, 6(7), 36-42.

Arora, A. (2016), Assessment of Financial Literacy amongst Working Indian Women. Business Analyst, 36(2), 219-237

Arrondel, L, Debbich, M., \& Savignac, F. (2013). Financial literacy and financial planning in France. Numeracy, 6(2), 1-17. https://doi.org/10.5038/1936-4660.6.2.8

Bahmar, Z. (2012). Investigating the relationship between financial literacy and prosperity and the determining association with demographic variables, Indian journals of fundamental and applied research (pp. 1143-11542).

Batra, A. (2013). Financial inclusion \& women empowerment: A Myth or Reality. International Journal of Research in Finance \& Marketing, 3(12), 16-25.

Beck, T., Demirguc-Kunt, A., \& Levine, R. (2008). Finance, inequality, and the poor. Journal of Economic Growth, 12, 27-49. https://doi.org/10.1007/s10887-007-9010-6

Beckmann, E. (2013). Financial Literacy and Household Savings in Romania. Numeracy, 6(2), Article 9. https://doi.org/10.5038/1936-4660.6.2.9

Bhushan, P., \& Medury, Y. (2013). Financial literacy and its determinants. International Journal of Engineering, Business and Enterprise Applications (IJEBEA), 4(2), 155-160.

Bonga, W. G., \& Mlambo, N. (2016) Financial Literacy Improvement Among Women in Developing Nations: A Case for Zimbabwe. Quest Journals, Journal of Research in Business and Management, 4(5), 22-31.

Bongomin, G. O. C., Ntayi, J. M., Munene, J. C., \& Akol, C. M. (2017). Financial intermediation and financial inclusion of poor households: Mediating role of social networks in rural Uganda. Cogent Economics \& Finance, 5, 1362184. https://doi.org/10.1080/23322039.2017.1362184

Dash, M., Prasad, V. M., \& Koshy, C. J. (2016). Women Empowerment through Microfinance Services. Journal of Applied Management and Investments, 5(1), 20-25.

Deka, P. P. (2015). Financial literacy and financial inclusion for women empowerment: A study. International Journal of Applied Research, 1(9), 145-148.

D.A.T. Kumari. (2016a). Financial Literacy as a Demand Side Antecedent of Financial Inclusion: An Empirical Study among rural poor in Sri Lanka. Wayamba International Conference (WinC 2016).

D.A.T. Kumari. (2016b). Psychological Barriers of Underprivileged Rural Customers in Adapting to Formal Financial System: A Study in a Selected DS Divisions of Kurunegala District. University of Colombo Annual Research Symposium 2016.

D.A.T. Kumari. (2017). Financial Literacy: An Essential Tool for Empowerment of Women through Financial Inclusion - Literature Review. Equality and Management. Faculty of Economics and Management, University of Szczecin, Poland.

Deka, P. P. (2015). Financial literacy and financial inclusion for women empowerment: A study. International Journal of Applied Research, 1(9), 145-148.

Devi, A. (2016). Financial literacy among women: A sample study in the Kamrup district of Assam. EPRA International Journal of Economic and Business Review, 4(2), 144-147.

Domingo, P., Holmes, R., O’Neil, T., Jones, N., Bird, K., Larson, A., Presler-Marshall, E., \& Valters, C. (2015). Women's Voice and Leadership in Decision-Making: Assessing the Evidence. London: ODI.

Ferdous, A. S., \& Polonsky, M. (2013). Predicting Bangladeshi Financial Salespeople's Ethical Intentions and Behaviour Using the Theory of Planned Behaviour: Implications for Developing Countries. Asia Pacific Journal of Marketing and Logistics, 25(4), 655-673. https://doi.org/10.1108/APJML-01-2013-0019 
Garg, N., \& Singh, S. (2018). Financial literacy Among youth. International Journal of Social Economics, 45(1), 173-186. https://doi.org/10.1108/IJSE-11-2016-0303

Ghosh S. (2019). Financial literacy and financial inclusion unbridling the nexus. Economic and Political Weekly, 54(13).

Golla, A. M., Malhotra, A., Nanda, P., \& Mehra, R. (2011). Understanding and Measuring Women's Economic Empowerment: Definition. Framework and Indicators. Washington, DC.

Hair, J. F., Hult, G. T. M., Ringle, C. M., \& Sarstedt, M. (2017). A Primer on Partial Least Squares Structural Equation Modeling (PLS-SEM) (2nd ed.). Thousand Oaks, CA: Sage. https://doi.org/10.15358/9783800653614

Hair, J. F., Gudergan, P., Ringle, C. M., \& Sarstedt, M. (2018). Advanced Issues in Partial Least Squares Structural Equation Modeling. Los Angeles: Sage.

Hair, J. F., Sarstedt, M., Ringle, C. M., \& Gudergan, S. P. (2018). Advanced Issues in Partial Least Squares Structural Equation Modeling (PLS-SEM). Thousand Oaks, CA: Sage. https://doi.org/10.3926/oss.37

Hasler, A., \& Lusardi, A. (2017). The gender gap in financial literacy: A global perspective. Washington, DC: Global Financial Literacy Excellence Center, The George Washington University School of Business.

Holvoet, N. (2005). The Impact of Microfinance on Decision-Making Agency: Evidence from South India. International Institute of Social Studies, 36(1), 75-102. https://doi.org/10.1111/j.0012-155X.2005.00403.X

Haque, A., \& Zulfiqar, M. (2016). Women's economic empowerment through financial literacy, financial attitude and financial wellbeing. International Journal of Business and Social Science, 7(3), 78-8.

Hung, A. J., Yoong, \& Brown, E. (2012). Empowering women through financial awareness and education. OECD Working Papers on Finance, Insurance and Private Pensions, No. 14, OECD Publishing.

Huston, S. J. (2010). Measuring financial literacy. Journal of Consumer Affairs, 44, $296-316$. https://doi.org/10.1111/j.1745-6606.2010.01170.x

Hoque, M., \& Itohara, Y. (2009). Women Empowerment through Participation in Micro-Credit Programme: A Case Study from Bangladesh. Journal of Social Sciences, 5(3), 244-250. https://doi.org/10.3844/jssp.2009.244.250

Islam, M. S., \& Reza, H. (2012). Micro-credit's efficiency and social overhead capital: GO-NGO coordination. Journal of Business and Management Sciences, 2(2). International Islamic University, Islamabad, Pakistan.

Isomidinova, G., \& Singh, J. S. K. (2017). Determinants of financial literacy: A quantitative study among young students in Tashkent, Uzbekistan. Electronic Journal of Business \& Management, 2(1), 61-75.

Jayamaha, R. (2008). Access to finance and financial inclusion for women. Colombo: Central Bank of Sri Lanka.

Joshi, M. C. (2013). India: Literacy and women's empowerment, a tracer study in ASPBAE (2012) The power of literacy: Women's journeys in India, Indonesia, Philippines and Papua New Guinea, Philippines: ASPBAE

Kabeer, N. (2005). Gender equality and women's empowerment: A critical analysis of the third millennium development goal. Gender and Development, 13(1), 13-24. https://doi.org/10.1080/13552070512331332273

Kabeer, N. (2012). Women's economic empowerment and inclusive growth: Labour markets and enterprise development. Department for international development, SIG working Paper, 2012/1

Karunathilaka, K. T. S. (2016). A Study on Financial Literacy of Rural Community in Sri Lanka: With Special Reference to Kurunegala District. 17th Conference on Postgraduate Research, International Postgraduate Research Conference 2016, Faculty of Graduate Studies, University of Kelaniya, Sri Lanka.174.

Kasman, M., Heuberger, B., \& Hammond, R. A. (2018). Recommendations for improving youth financial literacy education. Retrieved from https://www.brookings.edu/wpcontent/uploads/2018/10/ES_20181001_ FinancialLiteracy-Recommendations.pdf

Kempson, E., \& Whyley, C. (1999). In or out? Financial exclusion: A literature and research review, report, financial services authority.

Klapper, L., Lusardi, A., \& Van Oudheusden, P. (2015). Financial Literacy around the World. Washington DC: Standard \& Poor's Ratings Services Global Financial Literacy Survey.

Kumari, D.A.T., \& Aluthge, C. (2018a). Financial Literacy as an Antecedent of Financial Inclusion: An Empirical Study among Rural Poor in Kurunegala District, Sri Lanka, International Research Symposium, 
Social Science and Humanities (IRSSSH), National Centre for Advanced Studies in Humanities and Social Sciences Sri Lanka.

Kumari, D.A.T., \& Aluthge, C. (2018b). The Determinants of Financial Inclusion among Rural Poor: An Empirical Study in Sri Lanka, Wayamba International Conference, Wayamba University of Sri Lanka.

Kumari, V. G. L., \& Subrahmanyam. (2017). Women empowerment through financial inclusion - A study with reference to YSR Kadapa district of Andhra Pradesh. International Journal of Applied Research, 3(4), 509-513

Lusardi, A., \& Olivia S. M. (2014). The economic importance of financial literacy: Theory and evidence. Journal of Economic Literature, 52(1), 5-44. https://doi.org/10.1257/jel.52.1.5

Lusardi, A., Olivia, M. S., \& Vilsa, C. (2010). Financial Literacy among the Young: Evidence and Implications for Consumer Policy. CFS Working Paper 2010/09. https://doi.org/10.3386/w15352

Lusardi, A., \& Mitchell, O. S. (2009). How ordinary consumers make complex economic decisions: Financial literacy and retirement readiness. NBER Working Paper 15350. https://doi.org/10.3386/w15350

Lusardi, A., \& Olivia S. M. (2008). Planning and financial literacy: How do women fare? American Economic Review P\&P, 98(2), 413-417. https://doi.org/10.1257/aer.98.2.413

Lusardi, A., \& Scheresberg, B. (2017). Financial capability and financial literacy among working women: New insights. Retrieved from http://gflec.org/wp-content/uploads/2017/03/Research-Report_Working-Women_ March-2017.pdf x87657

Lusardi, A. (2019). Financial literacy and the need for financial education: Evidence and implications. Swiss Journal of Economics and Statistics, 155(1), 1-8. https://doi.org/10.1186/s41937-019-0027-5

Lyons, A. C., Grable, J., \& Zeng, T. (February 20, 2019). Impacts of Financial Literacy on the Loan Decisions of Financially Excluded Households in the People's Republic of China. ADBI Working Paper 923. https://doi.org/10.2139/ssrn.3370021

Madhubhashini Galagedarage, G. T. (2015). Issues in Internet Adoption and Rural Empowerment in Sri Lanka. Journal of Humanities \& Social Sciences, 9.

Maheswari, M., \& Revathy, B. (2016). Empowering women: Uncovering financial inclusion barriers. Advances in Social Sciences Research Journal, 3(4), 9-29. https://doi.org/10.14738/assrj.34.1563

Mayoux, L. (2000). Microfinance and the empowerment of women: a review of the key issues. Social Finance Unit Working Paper, 23, ILO, Geneva

Mayoux, L., \& Hartl, M. (2009). Women's empowerment through sustainable microfinance: Rethinking best practice.

Memon, Cheah, Ting, Ramayah, Chuah, \& Cheah, (2017). A review of the methodological misconceptions and guildlines related to the application of structural equation modeling: A Malaysian scenario. Journal of Applied Structural Equation Modeling, 1(1), 1-8.

Memon, Cheah, Ramayah, Ting \& Chuah, (2018). Mediation analysis issues and recommendations. Journal of Applied Structural Equation Modeling, 2(1), 1-9.

Memon, Cheah, Ramayah, Ting, Chuah, \& Cham. (2019). Moderation analysis: issues and guidelines. Journal of Applied Structural Equation Modeling, 3(1), 1-11.

Morgan P. J., \& Trinh, L. Q. (2019). Determinants and Impacts of Financial Literacy in Cambodia and Viet Nam. Journal of Risk and Financial Management, 12(1), 19. https://doi.org/10.3390/jrfm12010019

Mouna, A., \& Anis, J. (2017). Financial Literacy in Tunisia: Its determinants and its implications on investment behavior. Research in International Business and Finance, 39(Part A), 568-577. https://doi.org/10.1016/j.ribaf.2016.09.018

OECD. (2013). Financial literacy and inclusion: Results of OECD/INFE survey across countries and by gender. Paris: OECD Centre.

Peter, J. M., \& Long, Q. T. (2019). Determinants and Impacts of Financial Literacy in Cambodia and Viet Nam. Journal of Risk and Financial Management, 12(19), 1-24. https://doi.org/10.3390/jrfm12010019

Rai, K. (2019). Determinants of Financial Literacy: A Study Among Working Women in Delhi. Vivekananda journal of Research, 8(1), 194-213. 
Ramayah, T., Cheah, J., Chuah, F., Ting, H., \& Memon, M. A. (2016). Partial Least Squares structural equation modeling (PLS-SEM) using SmartPLS 3.0: An updated partial guide to statistical analysis. Singapore: Pearson.

Ringle, C. M., Sarstedt, M., Mitchell, R., \& Gudergan, S. P. (2018). Partial Least Squres Structural Equation Modeling in HRM Research. The International Journal of Human Resource Management. https://doi.org/10.1080/09585192.2017.1416655

Roy, B., \& Jain, R. (2018). A study on level of financial literacy among Indian women. IOSR Journal of Business and Management, 20(5), 19-24.

Saha, B. (2016). A study of financial literacy of working women of Raipur city International Journal of Recent Trends in Engineering \& Research (IJRTER), 2(11), 154-160. [ISSN: 2455-1457]

Sarstedt, M., Hair, J. F., Ringle, C. M., Thiele, K. O., \& Gudergan, S. P. (2016). Estimation Issues with PLS and CBSEM: Where the Bias Lies. Journal of Business Research, 69(10), 3998-4010. https://doi.org/10.1016/j.jbusres.2016.06.007

Sanjib. (2016). Financial literacy: Measurement and determinants. EPRA International Journal of Economic and Business Review, 4(6), 88-93.

Sarumathi, S., \& Mohan, K. (2011). Role of microfinance in women's empowerment: An empirical study in pendicherry region rural SHG's. Journal of Management and Science, 1(1).

Savitha, B., \& Polepeddi, J. (2011). Financial access and woman empowerment. Research journal of social science and management, 1(6), 166-175.

Sekaran, U., \& Bougie, R. (2016). Research methods for business: A skill-building approach (7th ed.). Haddington: John Wiley \& Sons.

Shiimi, I. (2010). Financial inclusion: An imperative towards Vision 2030: Annual Address. Bank of Namibia, Windhoek.

Siddik, N. A. (2017). Does Financial Inclusion Promote Women Empowerment? Evidence from Bangladesh, Applied Economics and Finance, 4(4). https://doi.org/10.11114/aef.v4i4.2514

Singh, C., \& Kumar, R. (2017). Financial literacy among women: Indian Scenario. Universal Journal of Accounting and Finance, 5(2), 46-53. https://doi.org/10.13189/ujaf.2017.050202

Standard \& Poor's Ratings Services Global Financial Literacy Survey (S\&P Global FinLit Survey), 2018. Retrieved from https://responsiblefinanceforum.org/publications/financial-literacy-around-the-world-insight s-from-the-standard-poors-ratings-services-global-financial-literacy-survey/

Taliaferro, D. L. (2011). A review of Howard University's financial literacy curriculum. American Journal of Business education, 4(10). https://doi.org/10.19030/ajbe.v4i10.6066

Taylor, S., \& Wagland, S. (2011). Financial literacy: A review of government policy and initiatives, Australasian Accounting Business and Finance Journal, 5(2), 101-125.

Thorat, A. (2006). Rural poor: Who are they and why? A Case Study of Madhya Pradesh. Journal of Social and Economic Development, 8(1), 41-67.

Tilakaratna, G. (2012). Dimensions and dynamics of client ship in the microfinance sector: Evidence from Sri Lanka. PhD Thesis (Unpublished). Manchester, UK: University of Manchester.

Upendra Singh. (2014). Financial literacy and financial stability are two aspects of efficient economy. Journal of Finance, Accounting and Management, 5(2), 59-76.

Vithanagama, R. (2016). Women's economic empowerment: A literature review. International Centre for Ethnic Studies (ICES), 2, Kynsey Terrace, Colombo 08, Sri Lanka.

\section{Copyrights}

Copyright for this article is retained by the author(s), with first publication rights granted to the journal.

This is an open-access article distributed under the terms and conditions of the Creative Commons Attribution license (http://creativecommons.org/licenses/by/4.0/). 